\title{
09
}

\section{La r-evolución del mecenazgo para la salvaguarda del patrimonio cultural}

Equipo Hispania Nostra

Todos a una es el nombre de la campaña de micromecenazgo que gestionamos desde Hispania Nostra. En nuestra asociación, de ámbito privado y sin ánimo de lucro, trabajamos desde 1976 por y para la defensa y puesta en valor del patrimonio natural y cultural común. Lo hacemos al servicio de la sociedad civil, actuando como órgano de información y difusión de contenido patrimonial cultural y natural, y promoviendo la participación ciudadana y la igualdad de oportunidades a través de acciones vinculadas a la educación patrimonial, la programación y promoción de jornadas y congresos, la gestión de la ya conocida Lista Roja del Patrimonio o la concesión de nuestros premios a las buenas prácticas. También son destacables las actividades que realizamos como representantes de Europa Nostra en España.

La necesidad, que es también responsabilidad, de dar voz a las demandas de la ciudadanía y tender puentes entre patrimonio y personas se materializa perfectamente en nuestro proyecto Todos a una. Se trata de la primera y única plataforma de crowdfunding dedicada exclusivamente al patrimonio cultural, una herramienta al servicio de todas aquellas personas que quieran poner su grano de arena en una serie de proyectos que requieren de financiación para seguir en pie o realizarse.
Lo extraordinario de este sistema de participación, y uno de sus rasgos más relevantes, es que su esencia misma parte de una idea de democratización, en este caso cultural, y de una consecuente descentralización en las acciones de protección y salvaguardia, que nos convierte a todos en posibles "interventores" de una realidad que señala y cuenta nuestra historia, nuestro pasado, nuestro presente y también nuestro futuro. La posibilidad de actuar que ofrece nuestra plataforma es en sí una llamada a la acción: insistir en la idea de que todos podemos tener un papel activo y positivo respecto al estado de nuestros bienes culturales y naturales es fundamental para empoderar a la ciudadanía, y recordarle su derecho, reconocido legalmente, a la protección del patrimonio.

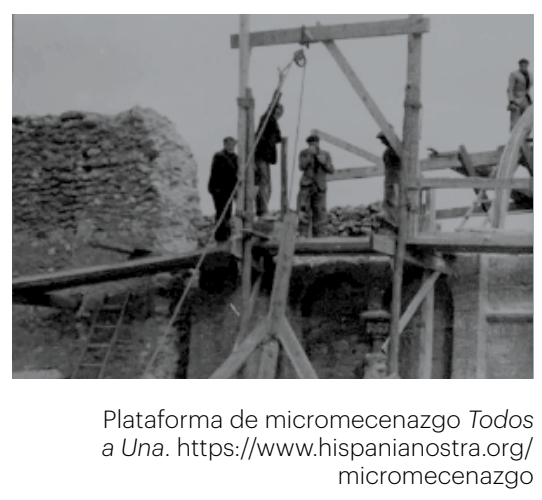




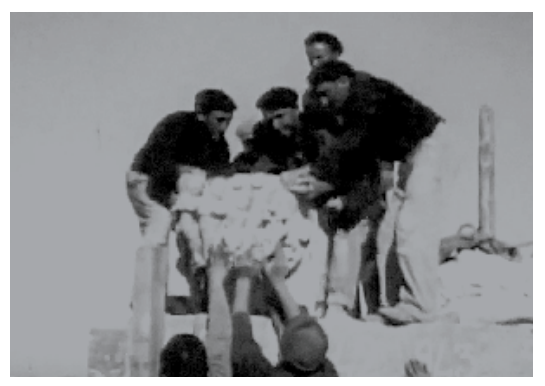

Plataforma de micromecenazgo Todos a Una. https://www.hispanianostra.org/ micromecenazgo

"La aparición del

micromecenazgo, crowdfunding 0 financiación colectiva propone precisamente un ejercicio de interacción y, sobre todo, de voluntad y complicidad social"
Como en todas las campañas de micromecenazgo, en Todos a una es la gente quien, en función de su utilidad y atractivo aporta al proyecto pequeñas donaciones (el mínimo es de 5 euros) hasta conseguir el objetivo final. No solo se busca financiación para la restauración, conservación y consolidación de obras, o para la adquisición de piezas por museos y la señalización del patrimonio, el abanico es muy amplio y abarca también proyectos puntuales como exposiciones, eventos culturales o publicaciones, por citar algunas posibilidades.

Un ejemplo de éxito e implicación colectiva fue la campaña para la recuperación de dos tesoros de alabastro del siglo XV. Dos relieves, de $82 \times 62,5$ centímetros cada uno, pertenecientes al sepulcro del arzobispo Alonso Carrillo de Acuña (1410-1482), que se creían destruidos y perdidos en la Guerra Civil, que fueron localizados en Londres y Corella respectivamente. A través de nuestra plataforma de micromecenazgo y del esfuerzo de los promotores, conseguimos los fondos necesarios (10.645 euros) para recuperar estas dos piezas, que han permitido la restauración de uno de los sepulcros más importantes de la escultura tardogótica española. Otro ejemplo es el palacio y los jardines de Bornos, que han obtenido este año el premio Hispania Nostra a las buenas prácticas.

Es importante señalar que nosotros facilitamos la plataforma, esto es, damos visibilidad a las propuestas, y en nuestro caso concreto también contamos con un equipo humano profesional e implicado que orienta y aconseja en la presentación y financiación de los proyectos; pero la publicidad, difusión y captación de donantes corresponde al promotor y no a la web, que es un mero escaparate donde exponer la idea.

Nuestra experiencia constata que, al contrario de lo que a veces se cree, el público donante se caracteriza por su heterogeneidad, siendo destacable la participación de usuarios y usuarias jóvenes. Esta diversidad de la gente interesada en cuestiones patrimoniales y la creciente participación de jóvenes apuntan ya hacia el éxito y confirman la necesidad de buscar canales actuales, accesibles y atractivos para dar a conocer cualquier aspecto de la realidad cultural; en este sentido, Todos a una resulta un recurso útil, necesario y adaptado a nuestro tiempo. 